\title{
Epidemiological clinical profile of COVID-19 cases in a municipality of Northeast Brasil
}

\author{
Adeilton Gançalves da Silva Junior ${ }^{1}$ \\ (iD) Klynger Farias da Costa ${ }^{1}$ \\ (iD) Paula Teles Vasconcelos ${ }^{1}$ \\ (iD) Tatiane Malta dos Santos 1 \\ (iD) Rodrigo Feliciano do Carmo 2,3 \\ (iD) Carlos Dornels Freire de Souza ${ }^{4,5}$
}

\begin{abstract}
1. Diretoria de Vigilância em Saúde, Secretaria Municipal de Saúde, Juazeiro, BA, Brasil 2. Pós-Graduação em Ciências da Saúde e Biológicas, Universidade Federal do Vale do São Francisco (UNIVASF), Petrolina, PE, Brasil. 3. Pós-Graduação em Biociências, Universidade Federal do Vale do São Francisco (UNIVASF), Petrolina, PE, Brasil. 4. Complexo de Ciências Médicas e Enfermagem, Departamento de Medicina, Universidade Federal de Alagoas (UFAL), Arapiraca, AL, Brasil. 5. Programa de Pós-graduação Em Saúde da Família (PROFSAÚDE/ FIOCRUZ/UFAL), Maceió, AL, Brasil
\end{abstract}

http://dx.doi.org/10.1590/1806-9282.66.5.573

KEYWORDS: COVID-19. Coronavirus infections. Epidemiology. Pandemics.

Dear Editor,

The first cases of COVID-19 were registered in Wuhan, a city of 11 million people in the People's Republic of China. Caused by the new coronavirus, SARS-CoV-2, the disease quickly spread across the world ${ }^{1}$. On March 11, 2020, the World Health Organization (WHO) declared a global pandemic ${ }^{2}$.

As of April 20, 2020, there were more than 2.49 million confirmed cases and 171,652 deaths from the disease in the world ${ }^{3}$. The first confirmed case in Brasil occurred on February 26, 20204. Since then, the disease has spread throughout the Brazilian territory, reaching cities in the interior. As of April 20, 40,581 cases and 2,575 deaths had already been registered in Brasil'.

Considering the spread of the disease in Brasil, this study describes the clinical and epidemiological profile of the first confirmed cases of COVID-19 in the municipality of Juazeiro, Bahia.

A descriptive study was carried out, based on data provided by the Health Department of the city of Juazeiro. The municipality is located in the Northern region of the state of Bahia, and it borders the city of Petrolina, which is located in the state of Pernambuco. Juazeiro has an estimated population of 210,000 inhabitants, and it is one of the most important centers of irrigated fruit in Brasil ${ }^{5}$. Clinical and epidemiological variables have been described.

The first suspected case in the municipality was notified on March 17, 2020. Between that date and April 20, there were 9 confirmed cases of the disease in the municipality. The first two confirmed cases were notified on March 17 and 18, 2020. Both were elderly individuals, members of the same family, with history of international travel. Community transmission was confirmed on March 31, with the notification of a nurse who had no travel history. The age of confirmed cases ranged from 22 to 77 years; four health professionals (two with higher education and 
two technicians) were confirmed with COVID-19. Cardiovascular disease, diabetes, and chronic respiratory disease were the comorbidities observed in three individuals. A 63-year-old man required hospitalization and died from COVID-19 (Table 1).

The observed profile is in line with the world literature $^{6}$. However, the following three reflections are necessary to understand the dynamics of the pandemic and its consequences: i. the importance of travelers in the chain of disease dissemination; ii. community transmission; and iii. the involvement of health professionals.

The importance of travelers in the chain of dissemination of the disease.

There is no doubt that national and international travel has contributed to the spread of SARS-CoV-2 around the world. To limit cross-border spread, both regionally and globally, many countries have swiftly adopted sweeping measures, including full lockdowns of shops and companies, shutting down airports, imposing travel restrictions, and completely sealing their borders in order to contain transmission?.

Restrictions on people coming from risk areas can be important at the beginning of an epidemic, as they allow control measures to be implemented in advance; however, they have little effect once community transmission has been established. According to the WHO, banning incoming flights from areas with high numbers of cases of COVID-19 does not prevent infected individuals from arriving from areas with intermediate numbers where controls are less stringent ${ }^{8}$. Furthermore, the movement of people between cities by land can also favor the spread of the disease regardless of air traffic.

The WHO thus recommends that travelers returning from affected areas self-monitor for symptoms for

TABLE 1.CHARACTERIZATION OF THE FIRST CONFIRMED CASES OF COVID-19 IN JUAZEIRO, BAHIA, NORTHEAST, BRASIL, 2020.

\begin{tabular}{|c|c|c|c|c|c|c|c|c|c|c|}
\hline Case & $\begin{array}{l}\text { Notification } \\
\text { Date }\end{array}$ & Sex & $\begin{array}{l}\text { Age } \\
\text { years }\end{array}$ & $\begin{array}{l}\text { Occupa- } \\
\text { tion }\end{array}$ & $\begin{array}{l}\text { Signs and symp- } \\
\text { toms }\end{array}$ & $\begin{array}{l}\text { Comorbid- } \\
\text { ities }\end{array}$ & Travel History & $\begin{array}{l}\text { Suspi- } \\
\text { cious } \\
\text { case } \\
\text { contact }\end{array}$ & $\begin{array}{l}\text { Hospi- } \\
\text { talized / } \\
\text { IMV }\end{array}$ & Outcome \\
\hline 1 & $03 / 17 / 2020$ & $F$ & 77 & Retired & $\begin{array}{l}\text { Cough, myalgia/ } \\
\text { arthralgia }\end{array}$ & None & $\begin{array}{l}\text { Yes } \\
\text { (São Paulo, } \\
\text { Africa, Dubai, } \\
\text { Abu Dhabi) }\end{array}$ & No & No & Cure \\
\hline 2 & 03/18/2020 & $M$ & 74 & Retired & $\begin{array}{l}\text { Fever, cough, run- } \\
\text { ny nose, irritability, } \\
\text { adynamia }\end{array}$ & $\begin{array}{l}\text { Cardio- } \\
\text { vascular } \\
\text { disease }\end{array}$ & $\begin{array}{l}\text { Yes } \\
\text { (São Paulo, } \\
\text { Africa, Dubai, } \\
\text { Abu Dhabi) }\end{array}$ & No & No & Cure \\
\hline 3 & 03/31/2020 & $F$ & 59 & Nurse & $\begin{array}{l}\text { Fever, cough, } \\
\text { myalgia }\end{array}$ & None & No & No & No & Symptomatic ${ }^{1}$ \\
\hline 4 & $04 / 08 / 2020$ & $M$ & 63 & Retired & $\begin{array}{l}\text { Fever, cough, } \\
\text { dyspnea, O2 satu- } \\
\text { ration < } 95 \% \text {. }\end{array}$ & $\begin{array}{l}\text { Cardio- } \\
\text { vascular } \\
\text { disease and } \\
\text { diabetes }\end{array}$ & No & No & Yes & Death \\
\hline 5 & $04 / 08 / 2020$ & $F$ & 32 & Nurse & $\begin{array}{l}\text { Cough, sore throat, } \\
\text { runny nose, head- } \\
\text { ache, nausea/vom- } \\
\text { iting, myalgia/ar- } \\
\text { thralgia, adynamia/ } \\
\text { weakness, enlarged } \\
\text { lymph nodes }\end{array}$ & None & No & Yes & No & Symptomatic $^{1}$ \\
\hline 6 & $04 / 11 / 2020$ & $\mathrm{~F}$ & 33 & Secretary & $\begin{array}{l}\text { Cough, headache, } \\
\text { diarrhea, myalgia/ } \\
\text { arthralgia }\end{array}$ & None & No & Yes & No & Symptomatic ${ }^{1}$ \\
\hline 7 & 04/13/2020 & $F$ & 25 & $\begin{array}{l}\text { Nurse } \\
\text { technician }\end{array}$ & $\begin{array}{l}\text { Runny nose, chills, } \\
\text { hoarseness }\end{array}$ & None & No & Yes & No & Symptomatic $^{1}$ \\
\hline 8 & 04/14/2020 & M & 22 & $\begin{array}{l}\text { Nurse } \\
\text { technician }\end{array}$ & $\begin{array}{l}\text { Cough, runny } \\
\text { nose, sneezing }\end{array}$ & None & No & Yes & No & Symptomatic $^{1}$ \\
\hline 9 & $04 / 15 / 2020$ & M & 69 & Retired & $\begin{array}{l}\text { Fever, cough, } \\
\text { dyspnea }\end{array}$ & $\begin{array}{l}\text { Chronic } \\
\text { respiratory } \\
\text { disease }\end{array}$ & No & No & No & Symptomatic $^{1}$ \\
\hline
\end{tabular}

Legend: F: female; IMV: invasive mechanical ventilation; M: male. 'Individual still without a clinical cure 
14 days. If symptoms, such as fever, cough, or difficulty of breath occur, travelers are advised to contact local healthcare providers, preferably by phone, and inform them of their symptoms and travel history ${ }^{8}$.

\section{Community transmission}

The Brazilian Ministry of Health recognized that community transmission was occurring across the country on March 20 as a strategic measure to ensure collective efforts to reduce transmission on the part of all Brazilians ${ }^{9}$. Since then, social distancing, store closing, and suspension of academic activities have been implemented by state governments as preventive measures.

Social distancing is one of the main methods to interrupt the disease transmission cycle, mainly due to the presence of asymptomatic carriers who may be able to transmit the virus. Accordingly, a recent study revealed that the viral load detected in asymptomatic patients was similar to that in symptomatic patients, which suggests the transmission potential of asymptomatic or minimally symptomatic patients ${ }^{10}$. Therefore, surveillance actions and expansion of testing are important to avoid the emergence of new cases.

\section{The involvement of health professionals}

The outbreak of COVID-19 could be particularly risky for healthcare workers due to their ongoing professional exposure to the virus. The National Health Commission of the People's Republic of China has reported that, as of February 24, 2020, a total of 3,387 out of 77,262 patients with COVID-19 (4.4\%) in China were healthcare workers or individuals who worked in medical facilities ${ }^{11}$. As of April 05, $2020,12,252$ health workers in Italy tested positive for COVID-19, accounting for 10\% of Italy's COVID19 cases; furthermore, 80 medical doctors and 25 nurses have died ${ }^{12}$. There are no official data from Brasil, but it is estimated that by the beginning of April, around 7,000 health professionals had been removed from work since the beginning of the pandemic due to suspicious symptoms.

Inadequate personal protection of healthcare workers at the beginning of the epidemic was a central issue since the form of contagion was not yet fully understood, and awareness of personal protection was not strong enough ${ }^{13}$. Today, with more information and protocols established to prevent COVID-19 infection, other issues contribute to the transmission of infection among health professionals, including the following: protective equipment (PPE) shortage, the intensity of work, and lack of rest ${ }^{13}$. Healthcare workers play a crucial role in combating COVID-19. Adequate provision of PPE, food, rest, and psychological support are essential measures to ensure the safety and quality of life of these professionals ${ }^{14}$.

In the present study, we describe the first cases of COVID-19 in the municipality of Juazeiro, Bahia, located in an important fruit center in the São Francisco Valley region. The cases are mainly composed of individuals with a history of travel in risk areas, health professionals, and contact with infected individuals. Tackling the pandemic is a complex process, which requires a wide range of measures to be developed simultaneously and in an articulated manner. No measure carried out in isolation will be able to contain the expansion of the pandemic.

\section{Authors' contribuitions}

Adeilton Gonçalves da Silva Junior: Participated in the concept and planning of the study, data collection and analysis, discussion of the results, drafting of the manuscript, as well as the revision and approval of the final version of the work.

Klynger Farias da Costa: Participated in the concept and planning of the study, data collection and analysis, discussion of the results, drafting of the manuscript, as well as the revision and approval of the final version of the work.

Paula Teles Vasconcelos: Participated in the concept and planning of the study, data collection and analysis, discussion of the results, drafting of the manuscript, as well as the revision and approval of the final version of the work.

Tatiane Malta dos Santos: Participated in the concept and planning of the study, data collection and analysis, discussion of the results, drafting of the manuscript, as well as the revision and approval of the final version of the work.

Rodrigo Feliciano do Carmo: Participated in the concept and planning of the study, data collection and analysis, discussion of the results, drafting of the manuscript, as well as the revision and approval of the final version of the work.

Carlos Dornels Freire de Souza: Participated in the concept and planning of the study, data collection and analysis, discussion of the results, drafting of the manuscript, as well as the revision and approval of the final version of the work. 
PALAVRAS-CHAVES: COVID-19. Infecções por coronavirus. Epidemiologia. Pandemias.

\section{REFERENCES}

1. Zhu N, Zhang D, Wang W, Li X, Yang B, Song J, et al. A novel coronavirus from patients with pneumonia in China, 2019. N Engl | Med. 2020;382(8):727-33.

2. World Health Organization. Coronavirus disease 2019 (COVID-19): situation report - 51. Geneva: World Health Organization; 2020. [cited 2020 Apr 20]. Available from: https://www.who.int/docs/default-source/coronaviruse/ situation-reports/20200311-sitrep-51-covid-19.pdf?sfvrsn=1ba62e57_10

3. Johns Hopkins University. COVID-19 Dashboard by the Center for Systems Science and Engineering (CSSE) at Johns Hopkins University (JHU). [cited 2020 Apr 20]. Avaliable from: https://coronavirus.jhu.edu/map.html

4. Brasil. Ministério da Saúde, Secretaria de Vigilância em Saúde. Doença pelo Coronavírus 2019. Boletim Epidemiológico do Centro de Operações em Emergência em Saúde Pública. Brasília: Ministério da Saúde; 2020.

5. Instituto Brasileiro de Geografia e Estatística (IBGE). IBGE cidade. 2020 [cited 2020 Apr 20]. Available from: https://cidades.ibge.gov.br/brasil/ba/ juazeiro/panorama

6. Guan WJ, Ni ZY, Hu Y, Liang WH, Ou CQ, He JX, et al. Clinical characteristics of coronavirus disease 2019 in China. N Engl | Med. 2020;382(18):1708-20.

7. Gostin LO, Wiley LF. Governmental public health powers during the COVID19 pandemic: stay-at-home orders, business closures, and travel restrictions. JAMA. 2020;10.1001/jama.2020.5460. doi:10.1001/jama.2020.5460.

8. World Health Organization. Updated WHO recommendations for international traffic in relation to COVID-19 outbreak. Geneva: World Health Organization; 2020. [cited 2020 Apr 20]. Available from: https://www.who. int/news-room/articles-detail/updated-who-recommendations-for-international-traffic-in-relation-to-covid-19-outbreak

9. Croda J, Oliveira WK, Frutuoso RL, Mandetta LH, Baia-da-Silva DC, BritoSouza JD, et al. COVID-19 in Brasil: advantages of a socialized unified health system and preparation to contain cases. Rev Soc Bras Med Trop. 2020;53:e20200167. Doi: 10.1590/0037-8682-0167-2020.

10. Zou L, Ruan F, Huang M, Liang L, Huang H, Hong Z, et al. SARS-CoV-2 viral load in upper respiratory specimens of infected patients. N Engl | Med. 2020;382(12):1177-9.

11. Zhan M, Qin $Y, X u e X$, Zhu S. Death from COVID-19 of 23 health care workers in China. N Engl J Med. 2020; NEJMc2005696. doi:10.1056/ NEJMc2005696.

12. Chirico F, Nucera G, Magnavita N. COVID-19: protecting healthcare workers is a priority. Infect Control Hosp Epidemiol. 2020;1-4. doi: 10.1017/ ice.2020.148

13. Wang |, Zhou M, Liu F. Reasons for healthcare workers becoming infected with novel coronavirus disease 2019 (COVID-19) in China. J Hosp Infec. 2020. doi: 10.1016/j.jhin.2020.03.002.

14. The Lancet. COVID-19: protecting health-care workers. Lancet (London, England). 2020;395(10228):922. doi: 10.1016/S0140-6736(20)30644-9. 